УДК 342(477)

DOI https://doi.org/10.51989/NUL.2021.6.10

\title{
РОЛЬ ЄВРОПЕЙСЬКОЇ КОНВЕНЦІЇ ПРО ЗАХИСТ ПРАВ ЛЮДИНИ І ОСНОВОПОЛОЖНИХ СВОБОД У СТАНОВЛЕННІ КОНСТИТУЦІЙНОГО ПРАВА НА СПРАВЕДЛИВИЙ СУД: ПРОБЛЕМИ ІНКОРПОРАЦІЇ
}

\author{
Завальнюк Ігор Вікторович, \\ кандидат юридичних наук, \\ суддя Одеського окружного адміністративного суду \\ ORCID: 0000-0002-6387-0199
}

У статті досліджено проблеми інкорпорації Європейської конвенції про захист прав людини і основоположних свобод та інших міжнародних документів у конституційні реалії становлення права на справедливий суд у державах Європи, зокрема в Україні. Зазначено, що проблема співвідношення національного і міжнародного права в регулюванні справедливості судового розгляду $\epsilon$ лише частиною більш загальної проблеми співвідношення внутрішньодержавного і міжнародного права, тому ї̈ дослідження вимагає належного врахування наукових уявлень фундаментального характеру. 3 аналізу конституцій держав Європи зроблено висновок, що їхні положення не суперечать нормам про справедливий судовий розгляд, що містяться в ст. 14 Міжнародного пакту і ст. 5, 6 ЄКПЛ. Визначено, що міжнародне і конституційне внутрішньодержавне регулювання права на справедливий суд $\epsilon$ фактом ратифікації цих документів державами, тобто очевидних суперечностей між конституціями держав і нормами зазначених договорів немає, у співвідношенні ж інших норм національного права і міжнародних договорів все не так ясно, бо більшість конституцій не займається договорами з точки зору визначення їх місця щодо внутрішніх норм. Наголошено: якщо в законодавстві немає спеціальних приписів щодо співвідношення міжнародного договору із законами, то в межах тлумачення визнається його пріоритет щодо останніх як «lex specialis», оскільки такий договір регулює ті чи інші відносини, в яких держави самим актом узгодження домовилися про спеціальне регулювання. Зазначено, що є два варіанти вирішення питання співвідношення норм договорів із нормами законів. Перший варіант представлений ситуаціями, коли міжнародний договір володіє більшою юридичною силою, ніж закон. За такого варіанта конституції закріплюють, що норми договорів не можуть бути змінені або скасовані законом. Другий варіант вирішення питання співвідношення договору і закону - наділення міжнародного договору силою, яка $\epsilon$ рівною силі закону. Зазначено, що суперечності між міжнародними і конституційними документами бути не повинно, тим більше Конституція України розроблялася в кращих правових традиціях, що передбачає гнучкість їі інтерпретації. До таких знань належать і міжнародні юридичні стандарти, які Україна визнала для себе обов'язковими. Обґрунтовано, що повністю виключити появу таких розбіжностей не можна, оскільки, як показує судова практика іноземних держав, суперечки про конституційність міжнародних угод виникають порівняно часто. Констатовано, що на відміну від конституцій європейських держав, зокрема Нідерландів, Конституція України, не містить процедури усунення розбалансованості міжнародного і національного законодавства. Таким чином, зроблено висновок, що в Україні жодне правило міжнародного договору не може бути реалізовано у внутрішньонаціональних відносинах, якщо воно не узгоджується з державними конституційними законами і, власне, з Конституцією України.

Ключові слова: справедливість, справедливий суд, конституція, конвенція, міжнародний договір, інкорпорація, судовий розгляд, конституційне право, правосуддя.

Zavalniuk Ihor. The role of the European Convention for the protection of human rights and fundamental freedoms in establishing the constitutional right to a fair trial: problems of incorporation

The article examines the problems of incorporation of the European Convention for the protection of human rights and fundamental freedoms and other international documents into the constitutional realities of the formation of the right to a fair trial in European states and, in particular, in Ukraine. It is noted that the problem of the correlation between national 
and international law in regulating the fairness of judicial proceedings is only part of a more general problem of the correlation between domestic and international law, so its study requires proper consideration of scientific ideas of a fundamental nature. From the analysis of the constitutions of European states, it can be concluded that their provisions do not contradict the norms on a fair trial contained in Article 14 of the International Covenant and Articles 5 and 6 of the ECHR. It is determined that the International and constitutional domestic regulation of the right to a fair trial is a fait accompli of ratification of these documents by states, which means that there are no obvious contradictions between the constitutions of states and the norms of these treaties, but in relation to other norms of national law and international treaties, everything is not so clear, because most constitutions do not deal with treaties in terms of determining their place in relation to domestic norms. It is noted that if there are no special requirements in the legislation regarding the relationship of an international treaty with laws, then within the framework of interpretation, its priority in relation to the latter is usually recognized as "lex specialis", since such a treaty regulates certain relations in which states themselves have agreed on special regulation by the act of agreement. It is noted that there are two options for solving the issue of correlation between the norms of contracts and the norms of laws. The first option is represented by situations where an international treaty has more legal force than a law. In this version of the Constitution, it is stipulated that the norms of contracts cannot be changed or repealed by law. The second solution to the question of the relationship between a treaty and a law is to endow an international treaty with a force equal to that of a law. It is noted that, in fact, there should be no contradiction between international and constitutional documents, especially since the Constitution of Ukraine was developed in the best legal traditions, which implies flexibility in its interpretation. Such knowledge also includes international legal standards that Ukraine has recognized as mandatory. It is proved that it is impossible to completely exclude the appearance of such disagreements, since, as the judicial practice of foreign countries shows, disputes about the constitutionality of international agreements arise relatively often. It is stated that unlike the constitutions of European states, in particular the Netherlands, the Constitution of Ukraine does not contain a procedure for eliminating the imbalance of international and national legislation. Thus, it is concluded that in Ukraine, no rule of an international treaty can be implemented in internal national relations if it is not consistent with state constitutional laws and, in fact, with the Constitution of Ukraine.

Key words: justice, fair trial, Constitution, Convention, international treaty, incorporation, judicial review, Constitutional Law, Justice.

Постановка проблеми. Ураховуючи те, що поняття справедливості змінюється в різні історичні епохи, сама постановка питання про загальне поняття справедливості, на наш погляд, стає необхідною, особливо коли йдеться про ії трактування з точки зору глобальних інтересів людства, природних і невід'ємних прав людини. Що стосується конституційного права, то дослідження поняття справедливості $\epsilon$ невід'ємною частиною теоретичної основи права на судовий захист, права на змагальний судовий процес, права на законний і справедливий розгляд. Вимога справедливого суду $\epsilon$ основоположним початком діяльності з урегулювання спорів, уналежнених до компетенції судів. Вихідним законодавчим джерелом цієї вимоги стала Конституція України, яка відображає демократичні принципи побудови сучасного українського суспільства. Поряд з іншими фундаментальними положеннями Конституція України опосередко- вано вказує на віру в справедливість як на історичну традицію і невід'ємну частину моральної основи соціальної організації в межах нової української державності. Таким чином, дослідження конституційно-правових аспектів здійснення справедливості, особливо в процесі судового розгляду, на сучасному етапі становить значний теоретичний і практичний інтерес. Проблема справедливості судового розгляду в конституційно-правовому полі має багатогранний характер, через що її розгляд передбачає всебічний комплексний підхід, дослідження різних аспектів.

Метою статті $\epsilon$ дослідження проблем інкорпорації Європейської конвенції про захист прав людини і основоположних свобод та інших міжнародних документів у конституційні реалії становлення права на справедливий суд у державах Європи, зокрема в Україні.

Аналіз наукових публікацій. Питанням дослідження поняття справедливості 
у сфері конституційного права присвячено увагу таких учених, як Р. Авдюгін, О. Антонюк, М. Аракелян, Н. Банникова, Ю. Барабаш, О. Біляєвська, В. Бойко, В. Бонтлаб, В. Грибанов, П. Єлісейкін, Г. Жилін, А. Жуковський, А. Колодій, П. Крашенніков, В. Колісник, Т. Маляренко, А. Медвідь, Т. Партико, П. Рабинович, Ю. Самович, Г. Тимченко, Ю. Тодика, М. Хавронюк, 3. Шевчук та ін.

Виклад основного матеріалу. Дослідження права на справедливий суд $\epsilon$ невід'ємною частиною теоретичної основи конституційного права на судовий захист, на змагальний судовий процес, на законне і справедливе вирішення правового конфлікту. Право на справедливий суд становить право особи, що закріплюється в ст. 6 Конвенції про захист прав людини й основоположних свобод (далі - Конвенція), яка гарантує право на справедливий і публічний розгляд справи впродовж розумного строку незалежним і безстороннім судом, установленим законом, під час визначення цивільних прав і обов'язків особи чи під час розгляду будь-якого кримінального обвинувачення, що висувається особі [7]. У Конституції України сьогодні, на жаль, не повною мірою висвітлюється зазначене положення. Згідно зі ст. 55 Конституції України «кожному гарантується право на оскарження в суді рішень, дій чи бездіяльності органів державної влади, органів місцевого самоврядування, посадових і службових осіб. Кожен має право звертатися за захистом своїх прав до Уповноваженого Верховної Ради України з прав людини. Кожному гарантується право звернутись із конституційною скаргою до Конституційного Суду України з підстав, установлених цією Конституцією, та у порядку, визначеному законом. Кожен має право після використання всіх національних засобів юридичного захисту звертатися за захистом своїх прав і свобод до відповідних міжнародних судових установ чи до відповідних органів міжнародних організацій, членом або учасником яких $є$ Україна» [8]. Як видно зі змісту вказаної статті, вона розкриває тільки окремі аспекти права на справедливий суд і зовсім не згадує відповідного терміна. Справедливо вказати на існування Закону України «Про забез- печення права на справедливий суд» від 12.02.2015 р. № 192-VIII [16], яким урегульовується сучасне законодавство відповідно до вимог Конвенції, але слід визнати, що положення Конституції України потребують ефективнішого вдосконалення в цьому контексті [2].

Сьогодні фахівцям добре відомо, що наукові уявлення про права людини склалися далеко не відразу, а виявилися результатом досить довгого історичного процесу, суттєвий вплив на який часто здійснювали світоглядні, культурні, соціальні, релігійні та інші фактори. Поки що отримані знання не були систематизовані в три основні наукові доктрини класичну, некласичну і постнекласичну. Вони повністю висвітлені в юридичній літературі, тому немає сенсу детально їх аналізувати в межах нашого дослідження. Головне полягає в тому, що в базових точках дотику вони $\epsilon$ неантагоністичними і не враженими стагнацією, хоча динамічність окремих елементів залишає бажати кращого. Усе це породжує нові методологічні підходи до вирішення проблеми прав людини в сучасному світі, причому частина з них спрямована на обґрунтування доцільності визнання прав людини комплексною галуззю права.

Дійсно, якщо класичний концепт, заснований на персональних ідеях індивідуалізму, передбачає сувору автономізацію особистості в умовах соціального буття, то в некласичних судженнях свобода сильної персони вже не ставиться на чільне місце. Уважається, що держава існує якраз для того, щоб не стільки охороняти окрему особу, скільки виконувати суспільно значущі завдання. Тим часом у більш пізньому постнекласичному правовому вченні приходить розуміння того, що немає ніякої необхідності явно або приховано протиставляти особистість і суспільство, приватне і колективне, оскільки і те, і інше $\epsilon$ компонентами складного єдиного соціального механізму. Правам людини в широкому значенні стали надавати статус не тільки універсальних, а й загальних, a їх диференціація набула неповторної багатогранності. Так, залежно від суб'єктної ознаки виділили індивідуальні та колективні права, за формою закріплення їх поділили на природні і позитивні; 
за характером зв'язку з державою - права людини і права громадянина.

Ця картина прав людини демонструє кросскультурну взаємодію Заходу і Сходу, консолідацію позитивних рис традиційних і сучасних практик для підтримки і захисту людської гідності. У ній права людини оформлюються як різноманіття в єдності, презентуються поліцентрично і варіативно: у сфері дії прав задіяний нестандартний список суб'єктів. Крім індивіда, держави, народів (етносів), недержавних організацій до списку носіїв прав уналежнені наддержавні об'єднання, людська спільнота загалом, майбутні покоління, при цьому права всіх суб'єктів гармонійно співвіднесені [3, с. 56].

Особливу затребуваність фундаментальні доктрини, ідеї, судження про права і свободи людини отримали відразу після Другої світової війни, яка чітко показала, що людська спільнота гостро потребує розробки й ухвалення ефективних міжнародних правових актів, а не їх публічної імітації. Причому вони мають забезпечувати належний захист як писаних, так і неписаних прав і свобод (як окремого індивіда, так необмеженого кола осіб). Тому на етапі інтернаціоналізації прав людини була створена ціла система певних засобів і методів, спрямованих на всебічний захист порушених прав і свобод, до яких належать адміністративні дії, самозахист і, звичайно ж, судовий механізм. 3 організаційної ж точки зору початок оформленню системи було покладено в 1946 р., коли на Генеральній Асамблеї Організації Об'єднаних Націй (далі - ООН) було поставлено на відкрите обговорення питання про підготовку Міжнародного білля про права та утворення комісії з прав людини (далі Білль) [14, с, 119].

Спочатку передбачалося, що Білль структурно охопить собою загальні декларативні принципи; пакти, імперативні для держав, що їх ратифікували; способи перевірки, здійснення зобов'язань різними країнами. Однак цього не сталося і на третій сесії Генеральної Асамблеї $\mathrm{OOH}$, де 10 грудня 1948 р. була прийнята Загальна декларація прав людини [5], що закріпила відповідні права, складники, що, за влучним висловом Н. Пархомеко, $\epsilon$ «золотим фондом гуманітарного розвитку» $[14$, с. 121$]$.

Відомо, що Загальна декларація прав людини сконцентрувала в собі мінімальний набір прав і свобод людини. У ній знайшли своє відображення базисні думки про природні права, притаманні людям від народження, про дихотомію відносин держави і людини, про кореляцію індивідуального і колективного, а також про саморозвиток особистості через соціальний і культурний спосіб організації життя [5]. Зважаючи на найменування, цей акт не мав регламентувати порядок реалізації тих чи інших парадигм, до того ж деякі держави індиферентно поставилися до Декларації.

3 огляду на викладені нами причини та інші обставини, зокрема політичні, низка країн континентальної Європи, взявши за основу декларацію, виступилиз пропозицією про створення регіонального наднаціонального юридичного документа - Хартії прав, а також утворення спеціального суду, який наділявся належними контрольними повноваженнями. Ця Хартія, що отримала назву Європейської конвенції про захист прав людини та основоположних свобод, була підписана державами-членами Ради Європи 5 листопада 1950 р. і характеризується як один із найдосконаліших пан'європейських договорів у галузі прав людини, що $€$ зразком для інших міжнародних і конституційних актів. Наприклад, ії положення були враховані в процесі розробки Американської конвенції з прав людини (Пакт СанХосе, 1978 р.) та Африканської хартії прав людини і народів (1981 р.) [14, с. 223].

Цілком зрозуміло, що Конвенція не могла кардинально відрізнятися від Загальної декларації прав людини. У ній виразно проступають риси як класичної доктрини прав людини з їі зосередженням уваги на особистості, природності і недоторканності наявних від народження різних можливостей, так і некласичної, за якою повноваження, пов'язані з обов'язками, надаються групам індивідів. При цьому захист колективних прав забезпечується на судовому рівні. Так, відповідні гарантії отримують мінігрупи, як-от неурядові організації та інші громадянські інститути, якщо вони стали жертвами порушень із боку урядово-владних установ та їх посадових осіб [4, с. 85]. 
У другій половині XX ст. (не без впливу ідей про нове постіндустріальне середовище) погляди на права людини певним чином видозмінилися. Відбувся поступовий перехід від інтернаціоналізації прав до глобалізації. Ціннісно-особистісні універсальні поведінкові принципи і тези, стали тлумачитися у вигляді певного досягнення, призначеного для всього людства, характер правової патології перестає бути суворо персоніфікованим, замкнутим на конкретній людині [13]. Небезпека порушень, особливо системних, тепер сприймається і аналізується в регіональному чи планетарному масштабі. Усе це разом з елементами теорії правового постмодерну трансформувало Європейський міжнародний договір, тому були затверджені численні протоколи до Конвенції [25].

3 організаційної точки зору іманентні зміни не минули безслідно для окремих конвенційних положень. Наприклад, спочатку відповідальність за дотримання зобов'язань, узятих на себе учасниками Конвенції, була покладена на Європейську комісію з прав людини, Європейський суд із прав людини (далі - ЄСПЛ) і Комітет міністрів Ради Європи (далі - КМ РЕ). Усі скарги, з якими зверталися окремі заявники або держави, попередньо розглядалися Європейською комісією з прав людини щодо їх прийняття, які (за умов позитивного вирішення питання) передавалися до ЄСПЛ для остаточного врегулювання конфлікту в галузі права (в інших випадках скарга надходила до КМ Р€ для подальшого вивчення). Але з огляду на вступ до Ради Європи нових країн, а також розширення Європейського Союзу стала збільшуватися і кількість скарг, що подаються до наднаціональної судової установи. Задля підвищення ефективності судової процедури 11 травня 1994 р. був відкритий шлях для підписання Протоколу № 11 «Про реорганізацію контрольного механізму, створеного відповідно до Конвенції», який набув чинності 1 листопада 1998 р. У результаті перші два органи з вищеназваних були перетворені в постійний Європейський Суд із прав людини, а нагляд за виконанням його рішень був покладений на КМ РЕ [23].

Як показав час, це не вирішило всіх проблем, наприклад, пов'язаних з особливос- тями внутрішніх правових систем, оскільки суддя, нехай навіть найбільш кваліфікований, не може однаково добре знати специфіку національних правовідносин і розумітися у всіх юридичних особливостях. Утім реформування не зупинилося, що підтвердив відкритий для підписання Протокол № 14 від 13 травня 2004 р., який доповнює контрольну систему Конвенції. Проте ЄСПЛ став повноцінним контрольним органом тому, що тепер він одержав право отримувати індивідуальні скарги незалежно від ставлення до них державиучасника, при цьому в більшості держав, які вступили до Ради Європи, безумовно, не відразу, але сформувалося адекватне розуміння того, що рішення ЄСПЛ, у яких установлюється порушення прав людини, виносяться на користь тій чи іншій країні, допомагаючи їй забезпечити гідне застосування владою найрізноманітніших правових положень [25].

Україна також приєдналася до досліджуваного нами міжнародного документа, про що свідчить Закон України «Про ратифікацію Конвенції про захист прав людини і основоположних свобод 1950 року, Першого протоколу та протоколів № 2, 4, 7 та 11 до Конвенції» від 17 липня 1997 року № 475/97-ВР [17]. Це означає, що, з одного боку наша країна вступила в якісно новий етап взаємин із Радою Європи в межах побудови загальноєвропейського правового простору [15], з іншого - через ратифікацію одного з базових міжнародноправових актів більш повну реалізацію отримало положення ст. 9 Конституції України, на підставі якого «чинні міжнародні договори, згода на обов'язковість яких надана Верховною Радою України, $\epsilon$ частиною національного законодавства України» [8].

Це надзвичайно важлива новела, яка суттєво впливає на функціонування української правової теми. Зважаючи на ухвалення цього принципу відкрилася можливість прямої дії і застосування норм міжнародного права різними органами влади, включно із судами.

Отже, вести мову потрібно про впровадження в національну правову систему загальновизнаних принципів і норм права, а також міжнародних договорів. Причому, на жаль, відразу доводиться констатувати: 
в юриспруденційнійтеорії і практиці немає єдності думок щодо розуміння цих складних юридичних явищ, що негативно відбивається на правозастосовній діяльності. Провідними вченими-юристами висловлені різні точки зору з дискусійного питання, які досить повно відображені у вітчизняній спеціалізованій літературі: починаючи із сумнівів в існуванні в міжнародному праві будь-яких чітко зафіксованих принципів і норм і завершуючи детально обґрунтованими, об'ємними формулюваннями, що розкривають їх природу і критерії диференціації.

Не вдаючись у всі тонкощі спору, який тривалий час ведеться вченими, оскільки це не входить в завдання нашого дослідження, зауважимо, що більшість теоретиків не заперечують такі важливі обставини.

По-перше, неправильно вбачати в загальновизнаних принципах і нормах неоднорідність, адже загальновизнаний принцип це суть норма міжнародного права, тоді як не кожна загальновизнана норма $€$ принципом, тобто їх співвідношення міститься в системі категорії «вид - рід».

По-друге, названі категорії не містяться в будь-якому окремому нормативному правовому акті, тому в міжнародній практиці під ними розуміються звичайні норми (узагальнені норми стосовно принципів), що складаються під впливом фактичної поведінки держав, розцінювані ними як загальнообов'язкові. Принципи і норми відображені в положеннях величезного масиву двосторонніх і багатосторонніх міжнародних договорів, у міжнародноправових звичаях, у рішеннях міжнародних міжурядових організацій, міжнародних судів, у конституціях і законах різних держав, у рішеннях їх судових органів і в інших актах, але не кожне положення міжнародного договору або іншого акта може бути розцінено як загальновизнаний принцип або норма. Питання про загальновизнаність принципів і норм у кожному конкретному випадку вирішується правозастосовником із залученням у необхідних випадках експертів. Загальновизнаність певних принципів і норм міжнародного права справедливо пов'язують із тим, що в цій якості вони визнаються міжнародним співтовариством держав загалом у формі міжнародно-правових звичаїв [19].
По-третє, джерелом, формою існування загальновизнаних принципів і норм $€$ не тільки міжнародний звичай, а і такий, що набув чинності для тієї чи іншої держави договір, невиконання якого тягне за собою певну відповідальність.

Цікаво, що в наведеній вище конституційній нормі не згадується про таку умову інкорпорування міжнародного договору, зокрема Конвенції, в національну правову систему, як його ратифікація. Однак ст. 2 Закону України «Про міжнародні договори України» від 29.06.2004 р. № 1906-IV встановлює дефініцію такої процедури: «ратифікація, затвердження, прийняття, приєднання - залежно від конкретного випадку форма надання згоди України на обов'язковість для неї міжнародного договору». А у ст. 9 цього закону також установлюється, що «ратифікації підлягають міжнародні договори України: а) політичні (про дружбу, взаємну допомогу і співробітництво, нейтралітет), територіальні і такі, що стосуються державних кордонів, розмежування виключної (морської) економічної зони і континентального шельфу України, мирні; б) що стосуються прав, свобод та обов'язків людини і громадянина; в) загальноекономічні (про економічне та науково-технічне співробітництво), із загальних фінансових питань, із питань надання Україною позик і економічної допомоги іноземним державам та міжнародним організаціям, а також про одержання Україною від іноземних держав і міжнародних фінансових організацій позик, не передбачених Державним бюджетом України; г) про участь України у міждержавних союзах та інших міждержавних об'єднаннях (організаціях), системах колективної безпеки; ґ) про військову допомогу та направлення підрозділів Збройних Сил України до інших держав чи допуску підрозділів збройних сил іноземних держав на територію України, умови тимчасового перебування в Україні іноземних військових формувань; д) що стосуються питань передання історичних та культурних цінностей Українського народу, а також об'єктів права державної власності України; е) виконання яких зумовлює зміну законів України або ухвалення нових законів України; $\epsilon$ ) інші міжнародні договори, ратифікація яких 
передбачена міжнародним договором або законом України» [18].

Здавалося 6, усе більш-менш ясно. Однак наведена законодавча техніка не дає відповіді на головне питання: яким же чином співвідноситься міжнародне і внутрішньодержавне право й які наслідки виникають у разі неузгодженості міжнародних і конституційних правових положень?

У правовій науці $€$ три відправні концепції, в межах яких робилися і робляться спроби дати відповідь на таке складне питання: примату міжнародного права; верховенства внутрішньодержавного конституційного права; дуалістична точка зору. Згідно з першою концепцією міжнародне право застосовується у внутрішньодержавних конституційних відносинах безпосередньо і без обмежень, тим самим установлюючи для різних країн єдині правила поведінки й уніфікуючи їхню діяльність. Друга доктрина передбачає безумовне превалювання приписів національного права, але в умовах глобалізації вона фактично нівельована, оскільки ставить під сумнів існування самого міжнародного права. Дуалістичні погляди з часом зазнавали змін. Якщо в першій половині XX ст. прихильники названої концепції стверджували, що міжнародне і внутрішньодержавне конституційне право мають спільні точки дотику, але не взаємопроникнення, то в другій половині минулого століття вони відмовилися від суворої тези про те, що конституційні норми національного права не підлягають використанню в разі їх невідповідності міжнародним зобов'язанням держави [24].

Спираючись на ту чи іншу теорію, різні автори висловили нетотожні погляди на вищезазначену проблематику. Деякі правознавці дійшли такої думки: відсутність у Конституції України ратифікаційного аспекту не $\epsilon$ не випадковим, до того ж це питання обговорювалося законодавцями під час ухвалення цього найважливішого нормативно-правового акта та було не взято до уваги. Це означає, що потрібно враховувати момент значущості міжнародного правового договору для Конституції та всієї національної правової системи, оскільки він може вносити корективи в законодавство країни або встановлю- вати інші правила тільки для конкретного випадку, не зачіпаючи будь-яких принципових юридичних основ. Так, цілком зрозуміло, чому ратифікації потребують не всі міжнародні договори, а тільки видозмінювальні внутрішньонаціональні правові відносини. Окремі європейські теоретики, досліджуючи Конституцію України, змалювали цю ситуацію більш чітко. Наприклад, Р. Макдональд зазначає, що в Україні загальновизнані принципи і норми тяжіють над Основним Законом країни [25].

Інші вчені дотримуються зворотного висновку: Міжнародний договір має пріоритет щодо будь-яких законів, ухвалених на території України, окрім конституційних. Ю. Мелякова пише: «Конституція України в рамках правової системи держави володіє вищою юридичною силою щодо всіх внутрішньодержавних нормативних актів і норм, передбаченим міжнародним правом» [12]. Із нею солідарний М. Матузов, який зауважує, що, зокрема, Конвенція функціонує суто як конституційний інструмент, за допомогою якого в Україні відбувається визнання та захист прав, свобод людини і громадянина. 3 огляду на це, на конституційному рівні в нашій країні заперечується всеосяжний примат міжнародного права, але укладені угоди повинні сумлінно і добровільно виконуватися «pacta sunt servanda» [10].

Для вирішення цієї непростої проблеми корисно вивчити конституційний зарубіжний досвід, зауваживши, що державні утворення, визначаючи порядок взаємодії міжнародного і конституційного права, використовують матеріальну або формальну інкорпорацію міжнародно-правових угод або ж дотримуються автоматичних інтеграційних прийомів.

В окремих конституціях проголошується примат загальновизнаних норм міжнародного права, окрім постулатів конституційної властивості. Так, у ст. 8 Конституції Республіки Білорусь говориться: «... Білорусь визнає пріоритет загальновизнаних принципів міжнародного права і забезпечує відповідність їм законодавства. Hе допускається укладення міжнародних договорів, які суперечать Конституції». Одночасно Конституційний Суд Республіки (на підставі ст. 116 Конституції за пропозиціями Президента, Палати 
представників, Ради Республіки, Верховного Суду, Вищого господарського суду, Ради Міністрів) дає висновки про відповідність законів, декретів, указів Президента, міжнародних договірних та інших зобов'язань Республіки Білорусь, Конституції і міжнародно-правових актів, ратифікованих Республікою [21, с. 113].

Близькі за змістом правові сентенції простежуються в ст. 4 Конституції Казахстану: «Конституція має вищу юридичну силу і пряму дію на всій території Республіки. Міжнародні договори, ратифіковані Республікою, мають пріоритет перед її законами і ухвалюються безпосередньо, крім випадків, коли з міжнародного договору випливає, що для його застосування потрібне видання закону» [21, с. 221].

У Конституції Литви підкреслюється, що Литовська республіка в зовнішній політиці слідує загальновизнаним принципам і нормам міжнародного права, а в ст. 138 цього нормативно-правового акта наводиться перелік міжнародних договорів, які можуть ратифікуватися Сеймом. У ст. 105 Конституції Литви зазначається, що Конституційний Суд уповноважений приймати рішення про розбіжності між названими договорами та Основним Законом [21, с. 157].

Тим часом було 6 неправильним не згадати про наявність конституцій зі ще більш широким формально-правовим регламентуванням. Наприклад, ст. 7 Конституції Грузії говорить, що «Грузія визнає і дотримується загальновизнаних прав і свобод людини як неминущих і вищих людських цінностей. Здійснюючи владу, народ і держава обмежені цими правами і свободами як безпосередньо чинним правом» [21, c. 180$]$.

Отже, новітні конституційні нормативно-правові акти, ухвалені на пострадянському просторі, містять відомості про пріоритет загальновизнаних принципів, норм міжнародного права, а також міжнародних договорів або всіх разом чи однієї з юридичних констант. У конституціях повсюдно $є$ застереження про те, що укладення міжнародних договорів, що не узгоджуються з Основним Законом країни, не дозволяється або ж дозволяється, але після внесення поправок до тексту базового національного закону. Перевіркою ж узгодженості займається Конституційний суд належної держави. Це створює підґрунтя для нормального функціонування судової системи, оскільки суди загальної (спеціальної) юрисдикції, безпосередньо застосовуючи звичайні, а також договірні норми міжнародного права, чітко розуміють, що такі мають відповідати Конституції країни [20, с. 43].

У країнах так званої «старої європейської демократії» Конституції також в переважній кількості випадків виходять $з$ автоматичної інтеграції загальновизнаних принципів і норм міжнародного права договірного значення. Наприклад, у ст. ст. 54 і 55 Конституції Франції підкреслюється, що належним чином ратифіковані або схвалені міжнародні угоди мають силу, що перевищує силу внутрішніх законів, із моменту їх опублікування. Подібний примат діє тільки з парламентської згоди. Однак Конституція володіє більш високим юридичним авторитетом, тому в разі, якщо Конституційна рада Франції заявить про те, що міжнародне зобов'язання містить положення, які заперечують Конституції, то дозвіл на його ратифікацію або схвалення дається тільки після перегляду Основного Закону [21, с. 306].

Королівство Нідерланди зовні відступило від принципу абсолютного верховенства конституційного закону. У ст. 63 Конституції записано: «зміст міжнародних договорів може вступати в суперечність 3 окремими положеннями Конституції, якщо того вимагає розвиток міжнародного правопорядку» Всяка розбалансованість міжнародних і національних норм долається двома третинами голосів членів парламенту Нідерландів, після чого суди отримують право у своїх рішеннях посилатися на міжнародні договори, причому абсолютно обходяться увагою загальновизнані принципи [21, с. 276].

Це не означає, що в Нідерландах, як і в інших країнах, у яких міжнародні договори можуть діяти у внутрішньодержавній сфері, з легкістю підміняють національне конституційне законодавство нормами міжнародних договорів. Як випливає 3 направленої Нідерландами до Ради Європи доповіді, ще на стадії підготовки до укладення міжнародного договору розглядаються питання, пов'язані з оцінкою 
необхідності ухвалення нового або зміни чинного законодавства з метою реалізації, положень договору в національному праві. При цьому забезпечується ухвалення такого законодавства до того, як держава висловить згоду на обов'язковість для неї міжнародного договору, і введення його в дію до моменту, коли договір набуде чинності для Нідерландів.

Частина країн континентальної Європи дотримується матеріальної інкорпорації. Наприклад, Швеція, де для реалізації в національній правовій системі міжнародного договору необхідне прийняття внутрішнього дублювального законодавчого (адміністративного) документа [21, с. 93].

у Німеччині формальне включення договірних норм відбувається через видання процедурного розпорядження щодо їх застосування. Ст. 25 Основного Закону Німеччини вказує, що норми міжнародного права $€$ складником федерального права. Вони мають перевагу перед законами і породжують права й обов'язки безпосередньо для осіб, які проживають на території Федерації. Однак на підставі ст. 100 Конституції Німеччини, якщо щодо передбачуваного правового результату виникає сумнів у межах вирішуваного спору про право, суд має отримати рішення Федерального Конституційного Суду [21, с. 355].

Зважаючи на це, чимала роль відводиться Федеральному Конституційному Суду, незважаючи на те, що він не перевіряє акти державного права через призму міжнародних стандартів, тому в його рішеннях не можна виявити частих посилань на Конвенцію, присвячену основним правам людини. Федеральний Конституційний Суд витлумачив положення ст. 25 Конституції так: лише норми загального міжнародного права не потребують трансформаційного закону і безпосередньо включені в правопорядок країни, а також мають пріоритет перед федеральним національним правом, окрім конституційного.

Що ж стосується міжнародних договорів, то в ст. 59 Конституції Німеччини чітко визначено, що договірні акти, які регулюють політичні відносини Федерації або зачіпають питання законодавства централізованого характеру, оформляються федеральним законом, тобто після інкорпорування можуть безпосередньо використовуватися судами. Щодо цього певний імпульс практичному правозастосуванню додало рішення іншого суду, а саме Вищого Федерального Суду від 10 січня 1966 р., яким була обґрунтована можливість безпосередньої реалізації Конвенції судовими органами. Суд звернув увагу на те, що Німеччина приєдналася до Конвенції, про що свідчить їі офіційне опублікування як документа, що має силу закону, чим «законодавча влада Німеччини своїм схваленням підтвердила, що Конвенція про права людини створює підстави для прямих претензій і тому вона доповнює або поправляє німецьке законодавство в тих сферах, де воно їй не відповідає» [21, с. 360].

Першою Конституцією, яка проголосила тезу про міжнародний договір як складник правової системи країни, була Конституція США, ухвалена в 1787 р. У ній наголошується, що і Конституція, і закони Сполучених Штатів, видані для її виконання, і міжнародні договори, які укладені або будуть укладені від імені Сполучених Штатів, $\epsilon$ вищим правом країни, а судді йому підпорядковані незалежно від будь-яких суперечностей. Через це жоден штат не має права самостійно вступати в будьякі договори, союзи або конфедерації [21, c. 407].

Однак не можна забувати про те, що американське право належить до групи країн «common law», тобто має суттєві відмінності від Європейського континентального права. Тут судовий прецедент $\epsilon$ найважливішим джерелом правових взаємин, що зумовлює ментальність юридичного мислення, тому вельми актуальним $\epsilon$ не дослівний текст закону, а інтерпретація головного конституційного документа, адже, на думку колишнього голови Верховного Суду США Ч. Хьюджеса, Конституція - це те, що про неї кажуть судді. 3 огляду на це, доречно згадати постанови судді Дж. Маршалла, чия діяльність досі оцінюється американськими юристами далеко не однозначно. Цей суддя Верховного Суду США вперше в правозастосовній практиці держави скористався владними повноваженнями, пов'язаними із здійсненням конституційного судового контролю. У 1809 р. у справі «Мербері 
проти Медісона» він угледів конфлікт Конституції США і закону Конгресу, завдяки чому скасував його, оголосивши принцип верховенства Основного Закону, відтворений потім у справі 1826 р. «Фостер і Ілем проти Нельсона». Своїм рішенням Дж. Маршалл, який був до цього Головою Державного департаменту, з політичних міркувань фактично визнав так звані «самовиконувані» міжнародні договори, тобто ті, що не потребують видання внутрішньодержавних актів для їх використання, положення яких мають відповідати духу Конституції США. Справа «Мербері проти Медісона» виникла, здавалося 6, із пересічної ситуації, але набула видатного значення через сформовані в той період політичні причини. Це була перша справа Голови Верховного Суду Дж. Маршалла; вперше в американській доктрині оголошувалося, що федеральна Конституція $\epsilon$ вищим законом країни і що судова влада має право кваліфікувати будь-який закон Конгресу і штатів як неконституційний і недійсний у разі його суперечності Основному Закону [26, с. 80].

Зауважимо, що положення про конституційний судовий контроль залишаються злободенними і сьогодні, про що свідчить правозастосовна практика Верховного Суду США, який визнав починаючи з 1803 р. неконституційними близько 130 правил різних законів, інших постанов американських судів; зокрема, щодо однієї зі справ суд апеляційної інстанції встановив, що міжнародна угода про екстрадицію, укладена між США і Францією, суперечить четвертій поправці до Конституції США, внаслідок чого вона не знаходить свого застосування [26, с. 97].

Таким чином, нинішня американська судова практика складається так, що в разі появі різночитань між федеральним законом і міжнародним договором судді виходять із загальновідомої константи: наступний закон скасовує попередній, однак конституційні положення $€$ священними, їх долю норми міжнародного договору визначати не можуть.

Отже, більшість держав світу, базуючи своє законодавство на дуалістичній концепції співвідношення міжнародного і внутрішньодержавного конституційного права, вважають для себе можливим застосування міжнародного права у внутрішньонаціональній сфері, але за умов дотримання окремих попередніх умов, першорядною з яких можна назвати відповідність Конституції країни. Причому у випадку із «самовиконуваними» договорами доцільно усвідомлювати таку значущу обставину. Незважаючи на те, що вони втілюються в правовій реальності без видання додаткових внутрішніх актів, суди все ж побоюються їх прямого використання через можливу неузгодженість таких із національними нормативними правовими установками, а також унаслідок гіпотетичних латентних наслідків. У цьому сенсі правосвідомість суддів тяжіє до реалізації національних (порівняно із загальновизнаними міжнародними) принципів і норм договірного характеру. Більшість представників суддівського корпусу сприймають таку універсальну формулу: суд застосовує безпосередньо ті міжнародні юридичні директиви, які тим чи іншим способом вбудовані в національну правову систему (безпосередньо або опосередковано санкціоновані вищими судовими органами), а не саме міжнародне право.

Думається, що взаємодія міжнародного і конституційного права означає їх тісний зв'язок, але не поглинання одного іншим. Міжнародне право стандартизує різні інструменти юридичного регулювання, проте через відсутність єдиної наддержавної процедури примусу країн до виконання взятих на себе зобов'язань воно не може ефективно працювати без структурованої сукупності конституційних загальнообов'язкових правил поведінки. Норми міжнародного права не володіють абсолютною перевагою над внутрішньодержавними нормами Конституції, вони не «трансформуються», перетворюючись у внутрішньодержавні закони. Навпаки, тут взаємодію потрібно розуміти як зустрічний рух вищеназваних видів норм, створення іміджевої узгодженості за допомогою різних юридичних технік і методик [22].

Сьогодні можливо виокремити три способи матеріалізації загальновизнаних принципів і норм міжнародного права, а також договорів на українському конституційному національному просторі, зокрема і в судовій правонаступницькій практиці: 
- автономне застосування окремих складників частин міжнародного права після дотримання належних санкціонувальних процедур;

- спільне використання загальновизнаних принципів і норм обох правових комплексів, у процесі чого відбувається їх взаємне збагачення, доповнення і конкретизація;

- пріоритет застосування міжнародних правових положень, якщо вони не узгоджуються $з$ національними.

У кожному конкретному випадку суд під час вибору відповідного способу (як один з органів державної влади) здійснює встановлення принципів міжнародного права всередині «своєї» країни. При цьому, як відомо, подібна реалізація неможлива без з'ясування змістовної сторони юридичних норм, тобто вона супроводжується тлумаченням, інтелектуально-вольовою роботою зі знаходження справжньої суті правових приписів [9].

Інтерпретуючи принцип або норму міжнародного права, суддя, крім усього іншого, зобов'язаний враховувати як буквальний текст нормативного акту, так і тлумачення такого міжнародними судовими установами, сприйняти його через призму системності всього міжнародного правового середовища, а також наміри сторін при укладенні договору, тим самим виробляючи адаптацію норми до внутрішньо-національного законодавства.

Крім того, потрібно звертати увагу на наявні відмінності в правовій культурі та правосвідомості суб'єктів правовідносин. Ледь чи допустимо мати на увазі, що інтернаціоналізація внутрішнього права означає заперечення власних юридичних традицій і звичаїв. Навпаки, як показує досвід інших країн, судді, тлумачачи міжнародні конструкції, майже завжди враховують, наскільки той чи інший зовнішній елемент правового регулювання $\epsilon$ чужорідним монолітному організму. Як пише О. Ковлер, «внутрішньодержавне тлумачення міжнародного права не $\epsilon$ всюди однаковим. Ми маємо справу ні з чимось цілком міжнародним, ні цілком конституційним, а з гібридом, що виражає відносини між ними» [6].

Для українського суддівського корпусу така характеристика має стати з часом звичною, не потрібно ставити перед собою завдання повної гомогенізації конституційного внутрішнього права. Раціональне зерно тут полягає в тому, щоб під час тлумачення не відбувалося принципових непереборних розбіжностей міжнародних і конституційних норм, підміни їх справжнього сенсу. Водночас настільки ж небезпечно переоцінювати роль внутрішніх правових інститутів під час роз'яснення суті міжнародних документів, бо в результаті нівелюється їх особливе призначення [11].

«Ворожнечі» між міжнародними і конституційними документами бути не має, тим більше Конституція України розроблялася в кращих правових традиціях, будучи коморою «неявних» знань, що передбачає гнучкість ії інтерпретації. До таких знань належать і міжнародні юридичні стандарти, які Україна визнала для себе обов'язковими [1, с. 50].

у будь-якому разі повністю виключити появу таких розбіжностей не можна, оскільки, як показує судова практика іноземних держав, суперечки про конституційність міжнародних угод виникають порівняно часто. На жаль, на відміну від конституцій європейських держав, зокрема Нідерландів, Конституція України, не містить процедури усунення розбалансованості міжнародного і національного законодавства. Виходить, що в Україні жодне правило міжнародного договору не може бути реалізовано у внутрішньонаціональних відносинах, якщо воно не узгоджується $з$ державними конституційними законами і, власне, Конституцією України.

Висновки. Проблема співвідношення національного права і міжнародного в регулюванні справедливості судового розгляду $\epsilon$ лише частиною більш загальної проблеми співвідношення внутрішньодержавного і міжнародного права, тому ії дослідження вимагає належного врахування наукових уявлень фундаментального характеру. 3 аналізу конституцій держав Європи можна зробити висновок, що їх положення не суперечать нормам про справедливий судовий розгляд, що містяться в ст. 14 Міжнародного пакту про громадянські і політичні права і ст. 5, 6 ЄКПЛ. Міжнародне і конституційне внутрішньодержавне регулювання права на справедливий суд $\epsilon$ фактом ратифікації 
цих документів державами, тобто очевидних суперечностей між конституціями держав і нормами зазначених договорів немає. У співвідношенні ж інших норм національного права і міжнародних договорів все не так ясно, бо більшість конституцій не займається договорами з точки зору визначення їх місця щодо внутрішніх норм. Якщо в законодавстві немає спеціальних приписів щодо співвідношення міжнародного договору з законами, то в рамках тлумачення визнається його пріоритет щодо останніх як «lex specialis», оскільки він регулює ті чи інші відносини, в яких держави самим актом угоди домовилися про спеціальне регулювання. Необхідно зазначити, що $€$ два варіанти вирішення питання співвідношення норм договорів з нормами законів. Перший варіант представлений ситуаціями, коли міжнародний договір володіє більшою юридичною силою, ніж закон. За такого варіанта конституції закріплюють, що норми договорів не можуть бути змінені або скасовані законом. Другий варіант вирішення питання співвідношення договору і закону - наділення міжнародного договору силою, яка $\epsilon$ рівною силі закону.

\section{ЛITЕРАТУРА:}

1. Волошин Ю.О. Конституційно-правове забезпечення європейської міждержавної інтеграції: проблеми теорії і практики : дис. ... д-ра юрид. наук : 12.00.02. Маріуп. держ. гуманіт. ун-т. Маріуполь, 2010. 513 с.

2. Головатий С. Конституція України 1996 р. в системі європейського конституціоналізму. Право України. 1997. № 8. С. 6.

3. Дженіс М., Кей Р., Бредлі Е. Європейське право у галузі прав людини: джерела і практика застосування. Пер. з англ. Київ : АртЕк, 1997. 624 с.

4. Дір І.Ю. Захист громадянських прав людини в Україні у рамках Ради Європи : автореф. дис. ... канд. юрид. наук : спец. 12.00 .02 «Конституційне право: муніципальне право». Інститут законодавства Верховної Ради України. Київ, 2010. 242 с.

5. Загальна декларація прав людини; ООН; Декларація, Міжнародний документ. Голос України від 10.12.2008 р. № 236.

6. Ковлер А.И. Соотношение европейского конвенционного и национального конституционного права обострение проблемы (причины и следствия). Российский ежегодник Европейской конвенции по правам человека. 2015. № 1. C. 38. URL: http://narodirossii.ru/?p=9783 (дата звернення: 11.11.2020р.).

7. Конвенція про захист прав людини і основоположних свобод : міжнар. док. від 04.11.1950. Рада Європи. Урядовий кур'єр. 2010. 17 листоп. № 215.

8. Конституція України : Закон від 28.06.1996 р. № 254к/96-ВР. Відомості Верховної Ради України. 1996. № 30. Ст. 141.

9. Максимов С. Конституційний принцип справедливості судового розгляду: загальне та особливе. Вісник Академії правових наук України. 2009. № 3. С. 127-134.

10. Матузов Н. Коллизия в праве: причины, виды и способы разрешения. Правоведение. 2000. № 5. C. 225-244.

11. Медвідь А.Б. Загальна характеристика змін внесених Протоколами № 6 та № 7 до Конвенції про захист прав людини і основоположних свобод 1950 року. Науково-практичний юридичний журнал «Вісник вищої кваліфікаційної комісії суддів України». 2016 р. № 3. С. 45-50.

12. Мелякова Ю. Правотворчість у прецедентному і континентальному праві: герменевтичний аналіз. Вісник Національної юридичної академії України ім. Ярослава Мудрого. Серія: Філософія, філософія права, політологія, соціологія. 2012. № 2 (12). С. 126-143.

13. Міжнародний пакт про громадянські та політичні права: ратифіковано Указом Президії Верховної Ради Української РСР № 2148-VIII від 19.10.73. URL: https://zakon.rada.gov.ua/ laws/show/995_043\#Text (дата звернення: 11.11.2020р.).

14. Пархоменко Н. Джерела права: проблеми теорії та методології: монографія. Київ : ТОВ «Видавництво «Юридична думка», 2008. 336 с.

15. Про виконання рішень та застосування практики Європейського суду з прав людини : Закон України від 23 лютого 2006 року. Відомості Верховної Ради України. 2006. № 30. Ст. 260. 
16. Про забезпечення права на справедливий суд : Закон України. Відомості Верховної Ради України, 2015, № 18, № 19-20, ст. 132.

17. Про ратифікацію Конвенції про захист прав людини і основоположних свобод 1950 року, Першого протоколу та протоколів № 2, 4, 7 та 11 до Конвенції : Закон України від 17 липня 1997 р. Відомості Верховної Ради України. 1997. № 40. Ст. 263.

18. Про міжнародні договори України : Закон України від 29 червня 2004 р. № 1906-IV. Відомості Верховної Ради України, 2004, № 50, ст. 540.

19. Рабінович П. Основні права людини: поняття, класифікація, тенденції. Укр. часопис прав людини. 1995. № 1. С. 19-27.

20. Савчин М. Конституціоналізм і природа конституції : монографія. Ужгород : Поліграфцентр «Ліра», 2009. 372 с.

21. Современные конституции. Сборник действующих конституционных актов. СанктПетербург : Изд. Юрид. книж. склада «Право», 2005. С. 652.

22. Сердюк I. Методологічний аналіз інтерпретацій поняття «тлумачення норм права». Науковий вісник Дніпропетровського державного університету внутрішніх справ. 2014. № 3. С. 41-42.

23. Совесть Европы: 50 лет Европейскому Суду по правам человека. URL: https://www. echr.coe.int/Documents/Anni_Book_Chapter15_RUS.pdf (дата звернення: 09.11.2020р.).

24. L. Wildhaber, A constitutional future for the European Court of Human Rights. Human Rights Law Journal. Vol. 23, No. 5-7, 2002. p. 164.

25. Macdonald R., Matscher F., Petzold H. The European System of the Protection of Human Rights. Martinus Nijhoff Publishers, 2013. P. 59-60.

26. Weissbrodt, D. S., \& Newman, F. International Human Rights: Law, Policy, and Process. (1st Edition ed.) Anderson Publishing. 2020. 320 p. 